\title{
THE EFFICIENCY OF THE COMPLEX TREATMENT OF PATIENTS WITH CHRONIC GINGIVITIS
}

\author{
Nina Bagdasaryan*, Valery Erichev, Tatyana Aksyonova, \\ Marina Mitropanova, Yevgeniya Ovcharenko
}

Kuban State Medical University (KSMA), Krasnodar, Russia

\begin{abstract}
A method for the complex treatment of patients with chronic gingivitis is applied, including the application of trypsin in 1\% solution of sodium bicarbonate, topical medication Qudesan and sonication, using a curette scaler with the toe. The clinical efficiency of the proposed method in the dynamics of treatment 55 patients with chronic gingivitis is counted. The use of complex therapy in accordance with the described method allows us to achieve a total destruction of the microbial biofilm in 7-8 days, which significantly improves the health and condition of the periodontal tissues, as well as the general condition of the patients after 2-3 weeks.
\end{abstract}

Key words: Chronic gingivitis, complex treatment

DOI: $10.21175 /$ RadProc.2017.45

\section{INTRODUCTION}

Periodontal disease occurs in all age groups, including young people and even children. This contributes to the formation of "ill health" of the nation. Signs of involvement of periodontal tissues are already evident in 6-7-year-old children, they can be registered in more than a half of adolescents, whereas in adult population, their prevalence is $85-100 \%$. [7]. It is necessary to stress that if the human inflammatory periodontal disease takes place, then the quality of life activity deteriorates in proportion to the inflammatory process [2]. Oral mucosa is adapted to the permanent contact with a variety of microflora, resistant to various irritants, and the rich flora of the oral cavity [5]. The primary gum alteration is often caused by local stimuli [4], such as dental plaque: the soft calcular deposit and calculus, which are formed with the absence of oral cavity sanation, poor hygiene, anatomical features of the dento-alveolar system, changes in qualitative and quantitative microflora composition, thus reducing the protection body factors. A dynamic disbalance between the pathogenic effects of "dental" calculus (microbial attack), the protective forces of periodontal tissues and organism, leads to chronic periodontal inflammation chronic gingivitis [8]. One of the most important points in the treatment of gingivitis and other inflammatory periodontal diseases is the destruction of microbial biofilms. The structure of biofilms varies - they consist of microcolonies, having signaling molecules which cause behavior changes and affect the rate of microbial growth. A close contact between the microorganisms in biofilms increases the genetic exchange of information and, as a consequence, extends the rate of formation of resistant strains. Microbial products of some microflora representatives are food for others, and that fact determines the existence of complex food-chains within the biofilm [10]. A generally accepted view is that recovery comes as the positing for well-timed qualitative and effective treatment of gingivitis [9]. However, a number of questions remain relating to the effectiveness of the combined treatment of gingivitis and to achieving a stable therapeutic effect in this pathology. Year by year, elaboration of methods of the treatment guidelines becomes more extensive, such as the use of long-acting medications with antiinflammatory, hemostatics, healing, immunomodulating effect (pharmaceuticals, based on active peptides and bioantioxidant complex) [3]; multiple application of antimicrobial specimen, modulators of inflammation and regeneration [6]. Most authors provide the results of the treatment evaluation in the earliest phase - after 2 weeks, 1 and 6 months. It has been noted that, after 6-12 months, complex therapy index values are close to normal.

The aim of the study is to increase the effectiveness of the treatment and reduce the occurrence time of sustained remission of chronic gingivitis using the method of complex therapy.

\section{METHODS}

Oral cavity examination was performed on 55 patients, including 29 men and 26 women aged from 19 to 35 years, living in similar environmental conditions of Krasnodar and the Krasnodar krai, which were diagnosed with chronic gingiviti.

The complaints all examined patients included halitosis, bleeding gums during eating and brushing teeth, as well as symptoms of periodontal tissue inflammation: marginal and papillary gingiva edema and hyperemia, multitude of soft plaque and calculus.

\footnotetext{
*ninabagdasaryan919@gmail.com
} 
The oral cavity and periodontal tissue evaluation was performed by the complex dental examination using the traditional scheme, including main clinical methods, such as clinicoradiological, comprehensive treatment, dynamic monitoring and oral hygiene index (OHI-S), sulcus bleeding index (SBI), PMA index. Monitoring was conducted in Municipal State-budget Dental Policlinic № 1 and Department of Dentistry FPSU KSMA, after written IC from patients for examination and treatment. All patients were under medical supervision for 1 year, with control examination after 3, 6, 9, 12 months. Additionally used - profile questionnaire, which patients completed on initial consultation. A result of patient reported outcomes was that, in past medical history, 8 people had gastrointestinal disease (gastroesophageal reflux disease), 2 persons had chronic hepatitis $C, 10$ people had bad habits (smoking). The inflammatory process of marginal gingiva was identified in the background of poor oral hygiene of 37 people. The diagnosis of chronic gingivitis was made on the basis of clinical and radiological studies in accordance with ICD-10.

Treatment group (40 pers.) was provided with the complex treatment of chronic gingivitis (patent application № 2620556), which included: professional oral hygiene, then treatment or removal of non-treated teeth. After the performed treatment, during the first 5 days, the application of $1 \%$ sodium bicarbonate solution to the affected zone gingival, once a day for 5 minutes, was sequentially performed. It was followed by the scaler sonication of marginal gingiva and dentogingival sulcus by a curette with a toe, at a frequency of oscillation between $28-30 \mathrm{kHz}, 0.2 \mathrm{~W}$ of power, and working amplitude tool of 10-20 microns. After that, trypsin solution ( $5 \mathrm{mg}$ based on 1 tooth area) in $1 \mathrm{ml}$ of $1 \%$ sodium bicarbonate solution under individual protective splint to 1 hour was applied to gingival margin. Next five days, Qudesan medication was applied to the affected gums area for 10 minutes as local antioxidant and regenerative therapy to patients on daily basis. Complex therapy was carried out within 10 days, follow-up visits at 3, 6, 9, 12 months. The control group (15 per.) was treated according to the approved scheme [1]: professional oral hygiene, ultrasonic removal of supragingival and subgingival dental calculus and plaque, administration of local medications: Heparin ointment $30 \mathrm{~g}$, Lugol solution with glycerol $25 \mathrm{~g}$ metronidazole (Metrogil Dent gel 20 g), sea buckthorn oil, propolis, chlorhexidine 0.05\% solution, Rotokan extract solution $25 \mathrm{ml}$, "Solkoseril" ointment 20 g. Follow-up visits were carried out at 3, 6, 9 and 12 months. The complex therapy includes patient motivation and oral hygiene education with individual selection of dental hygiene products and correction of oral care practices. The statistical analysis of the data was performed using practical statistics. For the description of quantitative characters, we used the arithmetic mean (M) and standard error of mean (m), whereas we used the Student t-test $(\mathrm{t})$ for comparing test groups by variables.

\section{RESULTS}

The clinical picture of all patients in the treatment and control groups was characterized by severe gum bleeding on probing, hypaeremia, edema, cyanosis of gingival papilla. In most clinical cases, a moderate quantity of plaque in front group teeth on the lower jaw was determined. 14 patients had complaints about general well-being: periodic weakness, loss of appetite. In all cases, while the probing was performed, the periodontal connection integrity has been preserved and maintained. The spot X-ray examination and dental panoramic radiogram showed that the height of inter-alveolar septum is not compromised and that the integrity of the cortical plate tops was intact. During the treatment of all main groups of patients, after 1 week, there was a significant improvement of marginal gingiva condition, no evidence of bleeding gums (indexes OHI-S $-3.29 \pm 0.02$, PMA $-3.23 \pm 0.01$, SBI $-0.23 \pm 0.03$ ), and the general well-being was mend. Oral health status was "good". After 21 days of treatment, the patients' complaints did not show and, after conducting a complex treatment of all examined, the gingival margin has acquired a pale pink color: edema, gingival tenderness and bleeding were absent (Table 1).

Table 1. Dynamics indicators of the efficiency of treatment of patients with chronic gingivitis $(\mathrm{M} \pm \mathrm{m})$. Note: ${ }^{*} p \leq 0.05$ (relative to the control group data)

\begin{tabular}{|c|c|c|c|}
\hline \multirow[b]{2}{*}{ Index } & \multirow{2}{*}{$\begin{array}{l}\text { Complex } \\
\text { therapy } \\
\text { period }\end{array}$} & \multicolumn{2}{|c|}{ Patients groups } \\
\hline & & $\begin{array}{l}\text { Control group } \\
n=15 \text { per. }\end{array}$ & $\begin{array}{c}\text { Treatment } \\
\text { group } n=40 \\
\text { per. }\end{array}$ \\
\hline \multirow{7}{*}{ OHI-S } & $\begin{array}{c}\text { Before } \\
\text { treatment }\end{array}$ & $3.92 \pm 0.23$ & $4.35 \pm 0.12$ \\
\hline & $10 \mathrm{~d}$ & $3.83 \pm 0.34$ & $2.22 \pm 1.06^{*}$ \\
\hline & $21 \mathrm{~d}$. & $2.51 \pm 0.43$ & $2.35 \pm 1.06^{*}$ \\
\hline & $3 \mathrm{~m}$. & $3.33 \pm 0.16$ & $2.61 \pm 0.32^{*}$ \\
\hline & $6 \mathrm{~m}$. & $3.79 \pm 0.3$ & $2.1 \pm 0.81^{*}$ \\
\hline & $9 \mathrm{~m}$. & $3.22 \pm 0.27$ & $1.8 \pm 1.49$ \\
\hline & $12 \mathrm{~m}$. & $2.84 \pm 0.65$ & $1.53 \pm 1.2$ \\
\hline \multirow{7}{*}{ PMA } & $\begin{array}{c}\text { Before } \\
\text { treatment }\end{array}$ & $3.63 \pm 0.24$ & $3.55 \pm 0.13$ \\
\hline & $10 \mathrm{~d}$. & $1.58 \pm 0.15$ & $0.52 \pm 0.02 *$ \\
\hline & $21 \mathrm{~d}$. & $2.04 \pm 0.31$ & $0.52 \pm 0.02^{*}$ \\
\hline & $3 \mathrm{~m}$. & $1.74 \pm 0.01$ & $0.53 \pm 0.01^{*}$ \\
\hline & $6 \mathrm{~m}$. & $1.75 \pm 0.02$ & $0.72 \pm 0.18^{*}$ \\
\hline & $9 \mathrm{~m}$. & $1.55 \pm 0.18$ & $0.58 \pm 0.04 *$ \\
\hline & $12 \mathrm{~m}$. & $1.71 \pm 0.02$ & $0.36 \pm 0.18^{*}$ \\
\hline \multirow{7}{*}{ SBI } & $\begin{array}{c}\text { Before } \\
\text { treatment }\end{array}$ & $2.13 \pm 0.04$ & $1.85 \pm 0.04$ \\
\hline & $10 \mathrm{~d}$ & $1.33 \pm 0.09$ & $0.2 \pm 0.03^{*}$ \\
\hline & $21 \mathrm{~d}$. & $1.2 \pm 0.04$ & $0.2 \pm 0.03^{*}$ \\
\hline & $3 \mathrm{~m}$. & $1.06 \pm 0.18$ & $0.25 \pm 0.02^{*}$ \\
\hline & $6 \mathrm{~m}$. & $1.26 \pm 0.02$ & $0.3 \pm 0.07^{*}$ \\
\hline & $9 \mathrm{~m}$. & $1.2 \pm 0.04$ & $0.2 \pm 0.03^{*}$ \\
\hline & $12 \mathrm{~m}$. & $1.4 \pm 0.16$ & $0.2 \pm 0.03^{*}$ \\
\hline
\end{tabular}

After 3 and 6 months, in follow-up visits, was observed persistent clinical remission. During the follow-up visits every 9 and 12 months, 14 patients indicated the presence of small amounts of hard and 
soft plaque, gum bleeding was absent, the color of the marginal gingiva was pale - pink, and patients had no complaints. In the control group, the improvement was noted after 10-11 days, 2 weeks after the treatment, according to the approved scheme - 11 (74\%) patients still had complaints about the bleeding gums, marginal gingival, slight redness and papillary gingiva edema, so the clinical remission continued for 3 months. Throughout the entire period of control group observation, patients reported the presence of soft plaque and supragingival calculus mainly in the area of the lower jaw front teeth and premolars, while the bleeding of gums periodically occurred.

The quality therapy of the teeth surface, marginal gingiva and periodontal sulcus provides the slow formation of microbial biofilms. The analysis of the dynamics of the hygienic index OHI-S, PMA index and SBI for the entire period of therapeutic treatment and follow-up can be attributed to these parameters as the indirect indicators for destruction of microbial biofilms. Their reduction, after complex therapy, was $98.2-100 \%$ in the treatment, and $67-81 \%$ in the control group. A high result of the claimed method is provided through the integrated sequential use of a series of procedures, in particular, ultrasonic scaler cleaning surface of the teeth, the mucous membrane of the marginal gingiva and periodontal sulcus using a curette toe, which ensures a complete destruction of the microbial biofilm due to cavitation effect. Ultrasonic treatment result is the extracellular matrix destruction, which is immersed in the colonies of microorganisms, with a subsequent 1-hour application of trypsin solution in $1 \mathrm{ml}$ of $1 \%$ sodium bicarbonate solution on gums under the individual protective splint, indirectly attending anti-inflammatory, regenerating and proteolytic activity. The supplementary condition for the effective treatment is carried out after the ultrasonic treatment, as the antioxidant and regenerative local therapy with Qudesan medication, which prevents the formation of free radicals and reduces oxidative stress markers, stimulating the respiratory function of mitochondria and ATP synthesis.

\section{CONCLUSION}

The use of the complex treatment method for chronic gingivitis improves the efficiency of the treatment of this disease by $80-85 \%$.

\section{REFERENCES}

1. И. В. Формичев, Г.М.Флейшер, “К вопросу об изучении методов оценки гигиены полости рта населения России," Медицинский алфавит, т. 4, но. 20, стр. 35 - 39, 2013. (I. V. Fomichev, G. M. Fleischer, "On studies of oral hygiene evaluation methods of population in Russia," Medical Alphabet Journal, vol. 4, no. 20, pp. 35 39, 2013.)

Retrieved from:

http://www.medalfavit.ru/index.php?option=com k2\&vie $\mathrm{w}=$ item\&task=download\&id=24 9fodob495f9d1a9530eof2 7ff6c44bdc\&Itemid $=124$

Retrieved on: Jan. 23, 2017

2. А. К. Иорданшвили, А. В. Тихонов, А. Л. Арыев, С. В. Солдатов, “«Возрастная" эпидемиология заболеваний пародонта," Пародонтология, т. 15, но. 1, стр. 25 - 28, 2010. (A. K. Iordanishvili, A. V. Tihonov, A. L Aryev, S. V. Soldatov, "Age epidemiology of periodontal pathologies," The Periodontology Journal, vol. 15, no. 1, pp. $25-28,2010$.)

3. Т. Л. Рединова, О. В. Третьякова, “Сила давления зубной щетки при чистке зубов и ее значимость в развитии заболеваний пародонта," Пародонтология, т. 21, но. 1, стр. 53 - 57, 2016. (T. L. Redinova, O. V. Tretyakova, "Press force of teeth brush while brushing of teeth and its role in paradontium diseases development," The Periodontology Journal, vol. 21, no. 1, pp. 53 - 57, 2016.)

Retrieved from:

https://issuu.com/stomgazeta/docs/periodontology 78

Retrieved on: Jan. 23, 2017

4. А. И. Николаев, Л. М. Цепов, Практическая терапевтическая стоматология, 8-е изд., Москва, Россия: МЕДпресс-информ, 2008. (А. I. Nikolaev, L. M. Tsepov, Practical therapeutic dentistry, 8th ed., Moscow, Russia: MEDpress-inform, 2008.)

5. Л. А. Цветкова-Аксамит, С. Д. Арутюнов, Л. В. Петрова, Ю. Н. Перламутров, Заболевания слизистой оболочки рта и губ, 3-е изд., Москва, Россия: МЕДпресс-информ, 2009. (L. A. Tsvetkova-Aksamit, S. D. Arutyunov, L. V. Petrova, U. N. Perlamutrov, Diseases of mouth and lips mucous, 3rd ed., Moscow, Russia: MEDpress-inform, 2009.)

Retrieved from:

http://medpress.tmweb.ru/upload/iblock/6b8/o97 Zabole vanija-slizistoj-obolochki-polostia-jCvetkovat.pdf

Retrieved on: Jan. 23, 2017

6. V. Zijnge, M. B. M. van Leeuwen, J. E. Degener, F. Abbas, T. Thurnheer et al., "Oral biofilm architecture on natural teeth," PLoS ONE, vol. 5, no. 2, p. e9321, Feb. 2010.

DOI: 10.1371/journal.pone.0009321

PMid: 20195365

PMCid: PMC2827546

7. T. Do, D. Devine, P. D. Marsh, "Oral biofilms: molecular analysis, challenges, and future prospects in dental diagnostics," Clinical, Cosmetic and Investigational Dentistry, vol. 5, pp. 11 - 19, Feb. 2013.

DOI: 10.2147/CCIDE.S31005

PMid: 23674928

PMCid: PMC 3652372

8. C. Cafiero, S. Matarasso, "Predictive, preventive, personalised and participatory periodontology: 'the 5 Ps age' has already started,” The EPMA Journal. vol. 4, no. 1, pp. 5 -6 , Jun. 2013

DOI: $10.1186 / 1878-5085-4-16$

PMid: 23763842

PMCid: PMC3703280

9. В. В. Еричев, А. Н. Бондаренко и др., Учебнометодическое пособие (справочник) для врачейстоматологов, клинических ординаторов, Краснодар, Россия: Просвещение - Юг, 2016. (V. V. Yerichev, A. N. Bondarenko et al., International Classification of Dental Diseases based on ICD-1O (short variant), Krasnodar, Russia: Prosveshcheniye-Yug, 2016.) 10. S. Manthena, M. V. Rao, L. P. Penubolu, M. Putcha, A. V. Harsha, "Effectiveness of CoQ10 oral supplements as an adjunct to scaling and root planning in improving periodontal health," Journal of Clinical and Diagnostic Research, vol. 9, no. 8, pp. ZC26 - ZC28, Aug. 2015.

DOI: $10.7860 / J C D R / 2015 / 13486.6291$

PMid: 26436041

PMCid: PMC4576635

11. Клинические рекомендации (протоколы лечения), Стоматологическая ассоциация России, Москва, Россия, 2014. (Clinical Recommendations (Treatement Protocols), Dental Association of Russia, Moscow, Russia, 2014.) Retrieved from: http://www.e-stomatology.ru/director/protokols 30-092014/

Retrieved on: Dec. 15, 2016 